\title{
Between Folk and Lore: Performing, Textualising and (mis)Interpreting the Irish Oral Tradition
}

\author{
Vito Carrassi \\ University of Basilicata, Italy
}

Copyright (c) 2017 by Vito Carrassi. This text may be archived and redistributed both in electronic form and in hard copy, provided that the author and journal are properly cited and no fee is charged for access.

\begin{abstract}
Folklore, as a historical and cultural process producing and transmitting beliefs, stories, customs, and practices, has always thrived and evolved in the broader context of history and culture. Consequently, tradition and modernity have long coexisted and influenced one another, in particular in the world of folk narratives, orality and literature, storytellers and writers. Since the nineteenth century, folklorists (a category including a variety of figures) have collected, transcribed and published pieces of oral tradition, thus giving folklore a textual form and nature. However, folk narratives continue to be also a living and performed experience for the tradition bearers, a process giving rise to ever new and different expressions, according to the changing historical, social, cultural, and economic conditions. To be sure, folklore - and folk narrative - needs to be constantly lived and performed to remain something actually pertinent and significant, and not only within the oral and traditional contexts. Interestingly, between the nineteenth and the twentieth centuries, folklore increasingly came to be regarded as and transformed into an inheritance, a valuable, national heritage particularly fitting for those countries, such as Ireland, in search of a strong, national identity. In this light, folklore and folk narratives, beside their routine existence within their original contexts, were consciously "performed" by the official culture, which employed them in politics, education, literature, etc. In the process, it could happen that folk materials were dehistoricised and idealised, "embalmed" according to Máirtin Ó Cadhain, and even trivialised. This situation was turned into a fruitful and significant source of inspiration for the literary parody of Myles na gCopaleen (Flann O'Brien) who, in his Gaelic novel, An Béal Bocht, revealed the funny yet distressing truth of the Irish folklore being misunderstood and betrayed by the Irish themselves.
\end{abstract}

Key Words. Oral Tradition, Performance, Textualisation, Revivalism, Gaelicisation, Parody, Lauri Honko, Myles na gCopaleen (Flann O’Brien), Máirtin Ó Cadhain.

Resumen. El folklore, como proceso histórico y cultural que produce y transmite creencias, historias, costumbres y prácticas, siempre ha evolucionado en el amplio contexto de la historia y la cultura. Por consecuencia, la tradición y la modernidad se han influido mutuamente a lo largo del tiempo, particularmente en el campo de las narraciones populares, la oralidad y la literatura, los contadores de historias y los escritores. Desde el siglo XIX los folcloristas (que es una categoría que incluye una gran variedad de elementos) han recogido, transcrito y publicado 
fragmentos de esa tradición oral, proporcionando así al folclore una forma y una naturaleza textual. Sin embargo, las narrativas populares continúan siendo una experiencia viva para los que mantienen la llama de la tradición, en un proceso que da lugar a expresiones siempre nuevas y diferentes, de acuerdo con las condiciones cambiantes en el terreno de la historia, la sociedad, la economía y la cultura. Sin duda alguna el folclore (así como las narrativas populares) necesita una reactualización permanente de forma que mantenga su significado y actualidad, no sólo dentro de los contextos relacionados con la tradición. Resulta interesante comprobar que entre los siglos XIX y XX el folclore se había transformado, y así llegó a considerarse, en una herencia, algo valioso que había sido heredado por los habitantes de la nación, lo cual se adecuaba especialmente bien a países como Irlanda, que buscaban una sólida construcción identitaria. Desde este punto de vista, el folclore y las narrativas populares fueron "representados" por la cultura oficial, que los usó en la política, la educación, la literatura, etc. A lo largo de este proceso es posible que los materiales populares perdieran su historicidad y que fueran idealizados, "embalsamados" según la expresión de Máirtin Ó Cadhain, e incluso que llegaran a trivializarse. Myles na gCopaleen (Flann O’Brien) convirtió este estado de cosas en fuente de inspiración para sus parodias literarias, especialmente en su novela escrita en gaélico An Béal Bocht, pues ahí se revela el divertido, aunque inquietante, panorama del folclore irlandés que estaba siendo malinterpretado y traicionado por los propios irlandeses.

Palabras clave. Tradición oral, representación, textualización, revivalismo, gaelización, parodia, Lauri Honko, Myles na gCopaleen (Flann O’Brien), Máirtin Ó Cadhain.

\section{Folklore as a process or performance}

Defining the nature of folklore, or folk-lore, seems to be a crucial and quite controversial issue. Since the coining of the word by British archaeologist William Thoms in 1846, scholars have pondered upon and debated the concept of folklore, often suggesting brief and/or effective definitions intended, above all, to make a physiologically unstable and changing object of study, strongly influenced by the evolution of historical, social, and cultural contexts, a little clearer and steadier. Interestingly, after having reviewed some of the main definitions of folklore formulated by prominent American scholars - highlighting, in particular, the different understandings of the sub-concepts of "folk" and "lore" (Oring 1-17) 1 - Elliott Oring admits that "a definition is not really necessary" (17). We are dealing with a problematic and challenging field of research, where one may include a variable number of items and phenomena not exactly or strictly identifiable as folkloric (see, for instance, the list of "folklore forms" supplied by Alan Dundes, in Oring 2). It turns out to be more useful and constructive, in order to not "think of folklore as a collection of things", to conceive an orientation, "a perspective from which almost any number of forms, behaviours, and events may be examined" (Oring 17-18). Therefore, instead of trying to define what kind of cultural product folklore might be, and keeping its field of research within clear-cut boundaries, it appears to be more proper an approach to take into account the contextual and dialectic nature of its historical and cultural processes (Bronzini, Cultura popolare 29-52). This would mean to recognise and emphasise, beside permanencies and continuities - often only apparent or wished (Anttonen 43-44) - the emergence of adaptations and transformations, according to a paradigm of (re)creation rather than one of loss (48-51), also relying on a more active and multifaceted notion of "tradition", as famously argued, for instance, by Dan Ben Amos (97-131).

In this light, one can appreciate the theorisation of the Finnish folklorist Lauri Honko. In his view, rather than something fixed and bound, folklore is just a "process", in which he 
identifies a "first" and a "second life", both worthy of consideration and analysis, as witnesses of the historicity, the dynamism, the variability of folklore, along with the relationships linking it to the other cultural levels (Hovi 6-9). Honko detects no less than 22 stages in the "folklore process", 12 relating to its first life (39-48), and 10 relating to its second life (48-53). Obviously, this is not an absolute pattern, indiscriminately applicable wherever and whenever, but the specific theorisation of a particular scholar. However, if we consider it as a more general frame to be used in a cautious and flexible way, it can result profitably in the study of a variety of contexts, the Irish one included.

To conceive of folklore according to such an interpretive outline brings to the fore, among other things, a conception of it as a cultural performance historically and socially situated, as an actual expression of a human belief, ability, practice, more than as a potential item fixed in a text. Richard Bauman provides a seminal definition concerning performance and its meaning in terms of folklore and folkloristics:

In one common usage performance is the actual execution of an action as opposed to capacities, models, or other factors that represent the potential for such action or an abstraction form from it. ... Folklorists ... contrast text-centered perspectives, which focus on disembodied, abstract folklore items, with performance-centered perspectives, which are concerned with the actual use of folklore forms. The focus of debate on these issues centers upon how much and in what ways the script or score or folkloric tradition determines performance as against how much flexibility, interpretive choice, or creative opportunity rests with the performer. (41-42)

In fact, Bauman highlights two kinds of interaction operating within the historical, concrete existence of folklore, two dialectic processes that ultimately produce, shape and hand down the things through which folklore builds itself: the interaction between a traditional corpus coming from the past and the individual innovation of one or more performers of the present (diachronic level), as well as the interaction between the living and actual performances of folklore bearers - or, more generally, the social actors - and the textual items extrapolated from them by the work of folklorists (synchronic level). It is through this double interaction that we have to look at the folkloric phenomena, so as to figure out the history and the evolution of forms, functions and meanings of folklore in a given context.

\section{Folk narrative tradition: between orality and writing}

If we want to see this double interaction fully operating, it seems quite fruitful to address the field of folk narrative tradition and oral storytelling. Here the mutual influence between a past corpus of stories and their concrete borrowing and re-creating by individual storytellers is particularly evident and fundamental, as well as an increasingly complex relationship - due to the gradual rise of the discipline of folklore - between the performative, contextual nature of an oral narrative and its written, textual, scholarly formalisation. In this light, it is not surprising if the traditional storytelling, along with its study and collection, has achieved a prominent place and role in the broader context of folklore and cultural debate, providing, at the same time, a heritage to preserve and a field of historical changes and cultural exchanges. ${ }^{2}$

Therefore, if it is certainly important to identify the source of a given narrative, namely the performative and contextual moment of an oral storytelling - including the biographical individuality of the storyteller(s) - it is as much pertinent to see how this performance and its performer(s) are watched and evaluated by those who, subsequently, will convey their experience as audience into a textual item. I propose, for example, a description supplied by 
Tadhg Ó Murchadha (1896-1961), full time collector of the Irish Folklore Commission, in the 1930s:

He [the storyteller] sat on the hob beside the fire to tell the story, his eyes fixed upon me like two owls. His body was swaying and his limbs trembling with the intensity of the telling. He raised his voice now and lowered it again, as would an actor on the stage. You might think that he belonged no more to this present world of ours, but had gone back to the ancient world of the heroes and was trying to make that world live in his story. All the characters in the tale were living people to him. Listening to him one realized how great was the old-world art of the storytellers. (Danaher 109)

What we see here is the picture of a lost world, or rather of its remnants, both from the point of view of the collector - "Listening to him one realized how great was the old-world art of the storytellers" (109) ${ }^{3}$ - and of our experience as women and men of the present-day. Nevertheless, it is also a specific and more or less biased picture resulting from the textual reenactment (and the mnemonic effort) of a folklorist in search of genuine, authentic folk narratives and narrators on behalf of the Irish Folklore Commission (Briody, The Irish 103149). His work can be interpreted as the (re)collection of a past phase of folklore - of its first life - when the oral storytelling was an integral part of a living context in which it had an everyday, peculiar function. It was, therefore, for the members of a certain community, an ordinary rather than an extra-ordinary event, yet embedded within a more or less ritualised framework; something connected to a narrative tradition coming from the past - a specific lore - but also reshaped according to the present tastes, needs, uses of a specific folk. ${ }^{4}$ Once collected - for instance by a collector such as Tadhg Ó Murchadha - an oral narrative is extrapolated by its storytelling context, in order to be recorded, archived and published, so as to become a cultural (immaterial) heritage, whose importance depends on its preserving, representing and also enhancing a piece of a declining (or declined) past (Anttonen 52). In this manner, folklore enters a new phase of its history - its second life - where it will be approached, employed and performed by other people and according to other functions than the original ones.

When transferred on the written/printed page, a storytelling performance loses a number of its major, distinguishing, most expressive features, whereas those remaining become useless, having lost their actual function. As Kevin Danaher points out: "Some of the characteristics of the orally delivered tale, such as tone, cadence, emphasis of voice, mimicry, and gesture are entirely lost; other, such as alliteration and repetition, may seem turgid or redundant" (112). Hence, the published text is the outcome of a transition from the oral world of folklore to the written world of literature - a complex and hybrid transition, indeed, entailing several stages -5 where the living dynamism of a specific and transient performance, of an open event, is frozen once and for all and made an unalterable, closed system (Ong; Carrassi 4-7).

Nonetheless, the nature of oral transmission implies the constant re-creation of traditional narratives by individual storytellers - and their audiences: “... as a result of the transmission process from person to person, there will inevitably be variation. ... The presence of multiple existence and variation distinguishes folklore from so-called high culture and also from mass or popular culture" (Dundes, International viii). In this light, the search of "authenticity" - a concept all too often invoked when folklore enters its second life (Bendix 323) - appears to be scarcely pertinent and also misleading, because what is found on the field is not an original, untouched, unique text coming from an ancient, distant, even mythic past, but a narrative event fashioned through a present performance in dialectic connection with a plurality of past narrators, interpretations and contexts. What is more, the similar concept of "originality" - so important for those folklorists who imagined an "oral tale-telling world ... in 
which stories maintain a continuity of form and content across unfolding time and space" (Conrad 326) - needs to be reinterpreted and re-framed to be made fitting for the oral context of the traditional storytelling and storytellers, as stressed by Seán Ó Coileáin: "Briefly we may say that in an oral tradition, the original (if the term may be used at all) is not in the immediate version heard by the teller but all the possibilities of the storytelling tradition to which he belongs" (19).

On the other hand, orality has long coexisted, in a variety of ways and levels, with several and different forms of writing and printing, which include phenomena really essential in Irish (and European) history, such as the medieval and modern transcription of manuscripts to preserve the oral narratives concerning the Celtic past, or the collective readings aloud supplied by the few literates living in rural areas to their mostly illiterate fellows, or else the plentiful circulation, especially during the nineteenth century, of cheap reviews and chapbooks in which a great deal of traditional lore was collected and published, reaching a wide range of readers. In other words, the oral tradition emerges, spreads and changes within contexts blending the oral and the written words, as well as literate, semi-literate, and illiterate people. ${ }^{6}$

More specifically, throughout the nineteenth century, in the wake of the European romantic and nationalist movements, Ireland was characterised by a number of figures operating in similar hybrid situations, then dealing both with oral performances and written recordings, folkloric facts and literary requirements, popular and scholarly cultures, lower and higher social classes. Archetypal and remarkable, in this respect, is the case of Thomas Crofton Croker (1798-1854) who, like many of his contemporaries and successors - such as Samuel Lover, Patrick Kennedy, Lady Wilde, Jeremiah Curtin, Douglas Hyde, Lady Gregory, and William Butler Yeats, just to mention the best-known and most influential of them - was a researcher and a collector of folk narratives and, at the same time, an editor and re-creator of his materials. He was the first Irish intellectual addressing the oral and popular tradition in order to set it down on paper and obtain a literary work, rather than just ethnographic, as appears in his Fairy Legends and Traditions of the South of Ireland (1825), a sort of Irish counterpart to the Kinder-und Hausmärchen of the Grimm brothers, who highly appreciated and translated in German Croker's collection. Fundamentally, Croker fashioned a hybrid genre of narrative, resulting from what might be regarded as a kind of performance, I would say the literary performance, ${ }^{7}$ of a folklorist-writer who meant to confer order, congruence, wholeness to the inherent anarchy characterising the oral materials found on the field, so as to build a canon of folk narrative fitting for his aesthetic goals and educated readers: "Like many of his contemporaries, Croker was convinced that he knew better than the transmitters of tradition how legends should be structured and developed" (Hultin 307). Croker's anthologies, and after them many others throughout the nineteenth century - such as those employed by Yeats to gather his own collections (Thuente 64-71) - contributed to retrieve and preserve a significant part of Irish folklore, each according to the specific views and biases of their authors, who were thus documenting the first life of the oral tradition and, at the same time, were facilitating its transition into a range of second lives.

At this point, folklore underwent an ongoing process of selection and rework, in order to acquire a different usefulness, both to become ideologically and politically suitable from a national point of view, ${ }^{8}$ and to fulfil an intellectual and literary search for a (supposedly) genuine, ancestral, prominent identity. Above all, Irish folklore would become a means to (re)discover a purely Celtic identity - as expressly claimed by Douglas Hyde, in 1892, with his speech entitled "The Necessity for De-Anglicising Ireland" - ${ }^{9}$ effacing all that was alien to itself: "In Ireland the Celtomania in the later nineteenth and earlier twentieth century brought a new outlook. The oral tradition, particularly that of the Gaeltacht, was a window on a wonderful, heroic, Celtic past. Other phases of the past ... were ignored or dismissed as irrelevant" (Ó Danachair 31-32). As a consequence, a wealth of folk narratives (myths, legends, 
sagas, folktales) were not only collected, but also revised and/or more or less loosely interpreted, to provide a prestigious cultural heritage to oppose to the classic heritages of hegemonic cultures. ${ }^{10}$

\section{Revival and Revivalism}

Such an argument brings us to the so-called Irish Revival or Renaissance, that is to a period when Irish folklore was given a key and significant relevance. In a sense, the authors of this literary and more widely cultural movement - which thrived between the end of the nineteenth and the early decades of the twentieth centuries - may be regarded as working along the slippery boundary separating (and blending) the collecting of a folk narrative and its integration in a literary context; moreover, they were torn between the reverence for what was considered the survival of an ancient past and the actual needs of people heavily committed in the crucial issues raised by the present. As summarised by Georges D. Zimmermann: "the Literary Revival's treatment of Irish folktales and storytelling was both respectful (they were parts of a valuable inheritance) and free (they could be adapted to some specifically literary use, comic fantasy not excluded). ... Each writer was likely to find what he wished to see" (346, my emphasis).

In this perspective, the young William Butler Yeats, as a folklore collector and editor, perfectly exemplifies the hybrid status of the Revivalists and the multiplicity of possible options they had when addressing the folk narrative tradition. As Mary H. Thuente points out:

Yeats's own work as a folklorist illustrates this conflict in Irish folklore between scholarly accuracy and poetic imagination. His Fairy and Folk Tales of the Irish Peasantry ... reflects his search for an imaginative yet authentic depiction of Irish folklore which avoided the extremes of a ponderous scientific air on the one hand, and a bogus stage-Irish charm on the other. (71)

In other words, Yeats looked for a sort of middle-earth where to reconcile the contradictory notions of authenticity and imagination. In this sense, the most significant attempt is probably The Celtic Twilight, a quintessentially hybrid work, a really personal mélange made of firsthand fieldwork and autobiographical memories, folktales, legends and essays, through which one perceives, among other things, the author's intolerance of all those paradigms and taxonomies accountable for framing and immobilising the living dynamism of the folk narrative tradition, of its performances and performers. It is not surprising, therefore, that Yeats himself attempted to create pieces of (new) folklore from literature through his own Stories of Red Hanrahan, another hybrid work that "could be described within the category of pseudofolklore as pseudo-legend" (Foster 239), showing as well how blurred the boundary between folklore and literature was, how deep their mutual influence was. ${ }^{11}$

Indeed, revivalism and revivalist movements in general may be regarded as intrinsic sources of rewriting, refashioning, and even resurrecting of (allegedly) authentic oral traditions, in order to make them functional in changed contexts, including that of the political struggle. ${ }^{12}$ This could entail a partial, paternalistic and/or idyllic understanding of folklore on the part of folklorists - be they scholars, writers and/or politicians - who were culturally, socially and economically very distant from the poor and subaltern world of their informants. As a crucial issue on the way of a national and nationalist (re)building, ${ }^{13}$ the folkloric component of Ireland, at least from a symbolic and ideological point of view, was subsumed within the hegemonic framework of the ruling classes and gradually (re)shaped according to their plans, despite the 
actual views, needs and aims of the lower classes, who were seen as the main, living sources of folklore. As argued by Diarmuid Ó Giolláin:

Cultural heritage is part of identity. Not everything inherited from the past is considered worthy of preservation nor is every part of everyday culture symbolically significant. Stuart Hall argues that in every period the cultural process involves drawing a line, always in a different place, "as to what is to be incorporated into 'the great tradition' and what is not". ... It is the dominant groups that determine which elements are superior and worthy to be preserved. (58, my emphasis)

In this process, a key role was carried out through the so-called "Gaelicisation" of folklore, or the Gaelic Revival, a cultural and political phenomenon that emphasised the linguistic issue and gave special attention to the recovery and enhancement of the native language, Gaelic, along with all the traditions connected to it. ${ }^{14}$ Douglas Hyde, and the Gaelic League - which "from its foundation in 1893 had kept near the top of its cultural and political agenda the complete reform of the Irish education system ... making the language an important part of the national and secondary curricula around the turn of the century" (Denvir 50) - maybe represent the most significant embodiments of this phenomenon. They epitomize a struggle to achieve a sort of cultural purification - also against the Anglicism of the contemporary Anglo-Irish Revival $-{ }^{15}$ through the recovery and re-evaluation of the Irish language, which had been marginalised and censored by the British rulers and was even in danger of disappearing. ${ }^{16}$ As Ó Giolláin puts it:

The creation of a movement for the revival of the Irish language and the call for the placing of the language in a central place in Irish life gave new importance to folklore, as a means of knowing those parts of Ireland that were still Gaelic and as the inspiration for a literature which, unlike that of the Anglo-Irish revival, would be "true" to the original source. (114)

Douglas Hyde was also the first Irish collector to claim a scientific and objective approach to the folk narratives, supplying the "exact language" of the Gaelic storytellers, as well as acknowledging an essential role to the storytelling contexts and to the individual identity of his sources, unlike most of his predecessors, much more interested in the collection and textualisation of a lore than in an accurate comprehension of the folk, i.e. the actual bearers and performers of that lore. The following excerpt comes from the preface of Hyde's major narrative collection, Beside the Fire (1890), a work including the original Gaelic transcriptions side by side with their English translations:

... the chief interest in too many of our folk-tale writers lies in their individual treatment of the skeletons of the various Gaelic stories obtained through English mediums, and it is not devoid of interest to watch the various garbs in which the sophisticated minds of the ladies and gentlemen who trifled in such matters, clothed the dry bones. But when the skeletons were thus padded round and clad, although built upon folk-lore, they were no longer folk-lore themselves, for folk-lore can only find a fitting garment in the language that comes from the mouths of those whose minds are so primitive that they retain with pleasure those tales which the more sophisticated invariably forget. ... In the present book ... I have attempted - if nothing else - to be a little more accurate than my predecessors, and to give the exact language of my informants, together with their names and various localities - information which must always be the very first requisite 
of any work upon which a future scientist may rely when he proceeds to draw honey (is it always honey?) from the flowers which we collectors have culled for him. (xvi-xvii)

The Gaelic Revival, like many other nationalist revivals, ${ }^{17}$ gave rise to an idealisation and sublimation of the native language, regarding it as a repository of the ancient Irish virtues - to oppose to a debasing Anglicised present - as the only means to create an authentically Irish literature and art, not polluted by "the foreign modes of thought" and by "the corruption and crass materialism of our age" (McKibben 102; see also Hyde, "The Necessity"). Nevertheless, this deep concern for Gaelic language and culture led also to a different, more objective approach to the Irish folklore.

\section{A science of folklore}

A decisive development, indeed, in the history of Irish folklore was the transition from a literary and/or revivalist to a more scientific and systematic approach, especially following the establishment, in 1935, of The Irish Folklore Commission (Coimisiún Béaloideasa Éireann), whose goal was "to undertake the collection, preservation, classification, study and exposition of all aspects of Irish tradition" (Ó Catháin 98), by means of a collective and concerted effort managed by a centralized, governmental institution. This meant, in particular, a shift from a literary or ideological appropriation to a scholarly, methodical work of more accurate collecting (now supported by the early sound recording devices), cataloguing and spreading. In so doing, the new generation of folklorists gave rise to a quite different genre of textualisation, resulting from a dialectic interaction between a living bearer of an oral, local tradition and a (more or less) expert person - a bearer, indeed, of a specific set of instructions and operational rules (Briody, The Irish Folklore 227-259) - expressly appointed by the Irish Folklore Commission to travel throughout the country in search of folk materials to save from extinction through a faithful work of recording. Emblematic of this innovative trend were figures such as Séamus Ó Duilearga, Séan Ó Súillebháin, Caoimhin Ó Danachair, "chief representative of the second generation, or post-revival Irish folklorists ... who have no personal system of belief to corroborate, no romantic image of a fey and credulous peasantry to project" (Foster 218).

It is also true, however, that, once become an object of study and collection, folklore and its bearers may be forced into a sort of exotic distance and isolation, ${ }^{18}$ in order to preserve what is supposed to be original and authentic, but also to safeguard something still recognizable as folklore, that is something more or less patently different from, and not contaminated by, the modern, learned, urban, hegemonic culture embodied by the official organizations and their representatives. And this at the cost of keeping the traditional communities in a fated indigence which, so to say, is required to allow the survival of the tradition. In Ó Giollain's words:

Folklore was distant from the observer, necessitating a journey outwards from the big cities, westwards towards the most remote, isolated and backward rural districts, and downwards, towards the poorest and most humble stratum of settled rural society. ... In fact poverty and isolation were necessary to the specificity of folklore since prosperity and integration of necessity involved the assimilation of modern values inimical to it. ... Those who idealized the Gaeltacht, the locus of Irish folklore par excellence, were aware that it was among the poorest parts of rural Ireland. Moreover, the best storytellers and the best speakers of Irish were among the poorest of its inhabitants. (142-143)

The search for folklore, therefore, if not properly and responsibly designed and carried out, can easily transform into a regressive and idealised journey towards a faraway and wild world, 
where one believes they will find a past and lost dimension of her/his own culture, disregarding any concern for the actual situation lived by its bearers. This is a crucial and critical issue in the history of folklore studies and of Irish folklore in particular. ${ }^{19}$ An issue that I would like to address through the funny yet wry parody of a Gaelic novel written by one of the most imaginative authors of the twentieth century.

\section{Folklore and literary parody}

This author is Brian Ó Nualláin, alias Flann O’Brien (1911-1966). Through his works it appears quite clear how literature, resuming and reshaping the folk narrative tradition, may contribute to keep it alive and meaningful. At Swim-Two-Birds, the most famous novel of Flann O'Brien, published in 1939, is probably the finest embodiment of this concept. Here the Irish folklore, along with a number of literary genres, becomes the source and the subject of a sparkling and complicated construction, of an inter-textual and meta-literary game giving rise to a multi-layered and hybrid novel. Several characters of Irish folk narrative tradition, such as Fionn mac Cumhaill, the púca, the good fairy or the king Suibhne, freely interact with one another and with many other characters coming from a variety of contexts. ${ }^{20}$ All of them are reworked by the inventive and often surreal parody of an author who, in so doing, contributes both to the survival of folk materials and to their literary and cultural enhancement.

However, it is through another alter ego, Myles na gCopaleen - both as a novelist and as a satirical author of the "Cruiskeen Lawn" columns on The Irish Times - that Flann O'Brien emphasizes the relevance of (Gaelic) folklore for a bilingual artist, working on the boundary separating (and blending) ${ }^{21}$ English and Gaelic identities. From his vantage point, since his childhood, according to Anne Clissmann (5), Myles had a deep awareness and an accurate understanding about the real complexity and peculiarity of Gaelic language and culture; consequently, he could not endure the shallowness, the carelessness, the incompetence of many of his contemporaries who addressed that matter. Thus, Myles' main targets became the socalled "Gaeligores", namely, stricto sensu, the Irish language enthusiasts (and often deficient translators), but also, lato sensu, all those writers, intellectuals, politicians who, on the basis of generally ideological, even opportunistic biases, created a stereotypical, mythologised image of the Gaelic world. Hence, satire, black humour and wild inventiveness, so extensively present in his Gaelic novel, An Béal Bocht (1941, later translated to English as The Poor Mouth), are the tools by which Myles lambasted the Gaeligores and sketched an irreverent and illuminating picture of the troublesome relationships joining folk (Gaelic) culture and its learned (English) translation and interpretation, or else real life and conventional revivalism. ${ }^{22}$ Writing to Sean O'Casey, he said that An Béal Bocht "is an honest attempt to get under the skin of a certain type of 'Gael', which I find the most nauseating phenomenon in Europe" (qtd. in Clissmann 238). The main problem - from Myles' keen and sensitive point of view - was that "Gael has become a groove, a convention, a cliché" (Murphy 148), chiefly owing to "what Brian Ó Conchubhair calls 'the cultural nationalist cant that permeates the vast majority of novels in Irish during the Free State"" (143).

To be sure, throughout the early years of Ireland as independent state, political, nationalist, educational, and even folkloristic motivations led to the emergence and spreading of a literature in Gaelic prose ${ }^{23}$ in which individual creativity and literary merit were actually overlooked and subordinated to a limited and simplistic view of tradition as a depository of pure Gaelic language and culture. In other words, something that was deep-rooted in its context - a certain lore lived, used and managed by a certain folk - was purposely, and incongruously, raised to a literary dimension, in order to uphold a sort of a national, popular, edifying literature. In this light, the genre of Gaelic autobiography - perfectly embodied by the works of the "Islanders" Tomás Ó Criomhthain (the major - yet not the only - source of An Béal 
Bocht, ${ }^{24}$ in its turn a parodic autobiography of a true "Gael") and Peig Sayers - took the lion's share: its first-hand portraits of tough and exemplary lives of authentic Irish women and men were seen as the most appropriate means to shape and popularize a strong image of Irishness. ${ }^{25}$

Despite his deep love for the Gaelic language, and even his "genuine admiration" for Ó Criomhthain's novel (Murphy 143), Myles was completely at odds with those revivalists (and folklorists) who "saw the language purely in nationalistic terms"; indeed, "he abhorred the purist protectionists" (Hopper 30). I think that his "satirical dismissal of the pretensions of the Gaeligores" (Murphy 143) is clearer and sharper than anywhere else in the last part of Chapter 3 of An Béal Bocht's, entitled "The shanachee and the gramophone". This provides a brilliant and quite original parody of the misunderstandings arising from a reckless and unskilled approach of a folklorist to his living field of research. Through his satirical depiction of a contemporary and widespread phenomenon - the Gaeligores' journeys to the Gaeltacht Myles reveals a sort of cultural and even human incompatibility, owing to a lack of mutual understanding, between some (pseudo)scholars (or mere enthusiasts who believe or pretend to be scholars) and their informants. The former are described as literally blinded by their search of authentic pieces of Gaelic lore, which they are forced to record "under the cover of darkness"; in so doing, indeed, they are left in the dark of the real nature of their fieldwork:

There was a gentleman from Dublin travelling through the country who was extremely interested in Gaelic. ... Since folks thought that it was unlucky, the gentleman had a difficult task collecting the folklore tales from them. For that reason, he did not attempt to collect the folklore of our ancients and our ancestors except under cover of darkness when both he and the instrument were hidden in the end of a cabin and both of them listening intently. (na gCopaleen 431-432)

In fact, something weird and seemingly inconceivable is going to happen. The grunting of a pig is mistaken for Gaelic speech - and, accordingly, a pig is mistaken for an Irishman - even in its purest and most genuine expression, and this occurs in a setting characterized by darkness, blindness, drunkenness: an insightful and impressive metaphor to point up the difficulty to establish a true dialogue between the folk who preserve a tradition and the gentlemen who want to study and collect that tradition. We perceive, though in a grotesque and exaggerated way, a refusal or an ineptitude, on the part of certain scholars and intellectuals, to seriously address the cultural otherness actually embodied by a folklore that is rather regarded as an exotic and strange heritage of the past, a heritage to keep distant and safe from the touch of modernity and progress. ${ }^{26}$ What the author describes is an obsessive interest in the collection of a lore as "difficult" as possible, even "unintelligible", at the expense of an actual understanding of its human dimension, of the folk, not by chance here degraded to an animal status:

The creature was lost without delay in the darkness of the house but wherever he lay on the floor, the gentleman's heart leaped when he heard a great flow of talk issuing from that place. It really was rapid, complicated, stern speech ... but the gentleman did not tarry to understand it. He leaped up and set the machine near the one who was spewing out Gaelic. It appeared that the gentleman thought the Gaelic extremely difficult and he was overjoyed that the machine was absorbing it; he understood that good Gaelic is difficult but that the best Gaelic of all is well-nigh unintelligible. ... It was said later in the area that the gentleman was highly praised for the lore he had stored away in the hearing-machine that night. (na gCopaleen 432-433, my emphasis)

Where is the science here? Where is the reliability of a serious work of research? On the contrary, by means of his parody, Myles reveals the existence of a pseudo-science, which 
prefers to neglect an objective and rigorous understanding of Gaelic language, in favour of a rough and unaware collection of a lore de-contextualized and reified by a hearing-machine. But where is the lore? In effect, this is pig-lore, not folk-lore! This is lore without folk, so to say, a fetish created by the suggestible mind of a gentleman in search of something he believes to know, but that he actually ignores. However, the gentleman is not alone. According to Myles' account, Gaelic, if not correctly approached, can deceive an entire academic and international community, who turns its study into a silly farce:

These learned ones [gathered in Berlin] said that they never heard any fragment of Gaelic which was so good, so poetic and so obscure as it and that they were sure there was no fear for Gaelic while the like was audible in Ireland. They bestowed fondly a fine academic degree on the gentleman and, something more interesting still, they appointed a small committee of their own members to make a detailed study of the language of the machine to determine whether any sense might be made of it. (433)

Eventually, Myles seems to tell us that, in order to have a true and reliable picture of the Gaelic, a historically grounded more than an idealistic and ideological picture, one must turn to those who had preserved and continued to preserve that language through their actual and daily use, both in the ordinary speech and in the storytelling. After all, the few ones who still spoke and understood it, like the novel's protagonist, Bonaparte O'Coonassa, who finally unveils the (unintended?) trickery, certifying that "whatever word was uttered that night, came from our rambling pig" (433).

A blunt, disenchanted statement tellingly mirroring the thought of its author, but also of another great writer such as Máirtin Ó Cadhain (1906-1970), "someone with impeccable Irishlanguage credentials and someone who was also steeped in the Irish-language oral tradition since childhood" (Briody, "Dead Clay" 55), whose criticisms of Irish folklorists, therefore, have a striking relevance. ${ }^{27}$ What is more, his critical attitude shows many similarities with the views expressed by Myles through An Béal Bocht. One recognizes, indeed, a significant parallelism between these two contemporary writers who considered Gaelic folklore, despite its precariousness in front of a rising modernity, as a still living and active force of the present, even "a huge resource for cultural regeneration" (Briody, "Dead Clay" 61). Consequently, they criticized the attitude of those folklorists who had an antiquarian, conservative understanding of their matter of study - according to Ó Cadhain, "Irish folklorists were "embalmers and entombers' of tradition" ("Dead Clay" 61) - and treated the collected materials as dead or dying remnants of the past; as famously complained by Ó Cadhain in 1950, during "a perceptive and characteristically truculent lecture on folklore" (Ó Giolláin 150) before the Writers' Club: "Irish folklorists were interested in 'Dead Clay' ... and ignored the 'Living Clay" (Briody, "Dead Clay" 62). As extremely innovative and inventive artists, it is not surprising that both Flann O'Brien and Máirtin Ó Cadhain were intolerant of what they saw as a barren and pedantic approach to the Irish folklore, ${ }^{28}$ merely aimed at detecting and preserving what was regarded as an ancient and declining heritage. From their (over)sensitive point of view, scholars and collectors were inclined to neglect (more or less consciously) the dynamism of a living tradition which continued to be currently performed in a variety of contexts (not only in the countryside) and by a variety of people (not only male peasants): ${ }^{29}$ "Folklore ... belonged to all ages and classes" (62).

The Gaelic language, the folk narrative tradition, the art of storytelling certainly represented an invaluable heritage which undoubtedly legitimized the unprecedented work of collecting, archiving and disseminating, as well as of reviving and reinventing, carried out between the nineteenth and the twentieth century by so many Irish women and men. Nonetheless, these things arose from present and still living phenomena, denoting the 
inescapably historical nature of cultural processes ever forging something new and different from a traditional heritage, which was thus made still meaningful - if possible - in a changing culture and society. In this light, folklore, and in particular Gaelic folklore, came to be a broader and more complex reality, above all an integral part of modernity rather than an inert, though praised and enhanced, survival of the past. Ultimately, this meant to recognize the two or more lives a piece of folklore, for instance an oral narrative, can take on as a result of a synchronic and diachronic dialectic between its actual performers and performances and all the works giving it a textual form. In other words, it means to recognize the inseparable relationship joining folk and lore, or else, the whole life of folklore.

\section{Notes}

${ }^{1}$ On the scope and meaning of the concepts of "folk" and "lore", I deem still suitable the outline proposed by G.B. Bronzini (Folk-Lore 55-57), which summarizes their variety and complexity both from a semantic and a disciplinary point of view. According to the Italian scholar, the term "folk" can be interpreted, in an ascending order, as including only the lower classes (vulgus), an entire people or nation (natio) or the overall mankind (humanitas). The term of "lore", on the other hand, can identify the literature (oral, traditional, popular), the history (not written, not official, minor, primitive) or the psychology of the folk(s). In Bronzini's view, though, the various meanings of "folk" are encapsulated in the concept of "tradition" (through which he means the individual and collective processes of creation, preservation and transmission of culture within a human group), while "lore" can be read as a synonymous of "culture" (in its broadest anthropological meaning).

2 According to JoAnn Conrad: "In the genealogy of the modern study of folklore the role of (folk) narrative has been essential and foundational. Objects of both inquiry and preservation, these narratives were evidence (and remnants) of the rich (oral) traditions of the past, and thus served as justifications for their collection" (329).

${ }^{3}$ Cf. Séamus Ó Duilearga, "Irish Tales and Story-Tellers" (1963), (qtd. in Dundes, International 160): "The art of the folk-tale is in its telling. It was never meant to be written nor to be read. It draws the breath of life from the lips of men and from the applause of the appreciative fireside audience. Although there are still many Irish people who can tell the long and intricate märchen, it is but rarely now that they are told. The days of the folk-tale are numbered even in Ireland".

${ }^{4}$ According to Alan Dundes (quoted in Oring 1), "“Folk' can refer to any group of people whatsoever who share at least one common factor".

${ }^{5} \mathrm{Cf}$. Danaher: "In this way we may have, between the teller of the tale and its recipient, a transcriber, a translator, and an editor, any of whom may - and all of whom usually do - leave an idiosyncratic imprint on language, on style, or on content" (112).

${ }^{6}$ See, for instance, Schenda.

${ }^{7}$ Interestingly, Hultin points out that "Crofton Crokerish was a term to designate a style with which to recount Irish legends" (298).

${ }^{8}$ Cf. Dundes, International 153: "The smaller countries are often the ones in which interest in folklore has been the greatest. ... The reason for this might be that smaller countries have often feared for the loss of their identity, and inasmuch as identity is very much tied to folklore, nationalistic and patriotic scholars felt the necessity of preserving as much of their heritage - their precious folklore - as possible".

${ }^{9} \mathrm{Cf}$. Hyde, "The Necessity" 159, in particular this passage: "In a word, we must strive to cultivate everything that is most racial, most smacking of the soil, most Gaelic, most Irish, because ... this island is and will ever remain Celtic at the core, far more Celtic than most people imagine ...".

${ }^{10}$ See Dundes, "Nationalistic", and Casanova 303-323.

${ }^{11} \mathrm{Cf}$. Foster: "This attempted making of folklore, this weaving of history, folklore, and fiction were recurring tactics of the Irish literary revival" (239-240).

12 As pointed out by Heda Jason: "Revivals may often have political aspects: nationalistic movements tend to be accompanied by folklore revivals" (77).

${ }^{13}$ On this subject see in particular Hutchinson.

${ }^{14}$ For a detailed overview of this subject I would refer to McMahon.

15 See O'Leary, The Prose 281-354.

${ }^{16} \mathrm{Cf}$. Denvir: "In the period from 1800 to 1891 , a mere three generations, the number of Irish speakers declined from some three million, the great majority of whom would have almost certainly been monoglot, to the 38.121 monoglot speakers recorded in the census of 1891" (45).

${ }^{17}$ See in particular Casanova. 
${ }^{18} \mathrm{Cf}$. Anttonen: "Indeed, it is this mystery and power of the old and the exotic - the antique as a souvenir from unvisitable places - that often entices people to folklore studies" (50).

${ }^{19}$ Interesting, from this point of view, a chapter in Ó Giolláin (142-164) entitled "Folklore and

Poverty".

${ }^{20}$ On the use, function and meaning of these figures in At Swim Two Birds I would refer to the exhaustive study of Eva Wäppling.

${ }^{21}$ According to Myles na gCopaleen, "the Irish language was the secret ingredient that gave certain forms of Hiberno-English writing their distinct flavour" (Hopper 30).

${ }^{22}$ According to Jane Farnon, An Béal Bocht is "an amiable pseudo-autobiography which lashes out at the sterility of Gaelic literature and at the image of the idyllic, pastoral, contented Gael which the Literary Revival had cultivated" (89).

${ }^{23}$ See O’Leary, Gaelic, especially 90-164.

${ }^{24}$ As noted by Neil Murphy: “An t-Oileánach [The Islandman, the autobiographic novel of Tomás Ó Criomhthain] is but one text that Myles references in An Béal Bocht. Many critics have pointed to the novel's parodic relationship with the works of Séamus Ó Grianna, Muiris Ó Súillebháin, Peig Sayers, Peadar Ó Laoghaire, Tomás Ó Maille and with the Immram Curaig Máele Dúin (The Voyage of Máel Dúin) saga. And it goes far deeper than this. The specific level of engagement with each of the above, as well as with authors such as W.B. Yeats, John Millington Synge and Brian Mac Giolla Meidhre (Brian Merriman), invites one to reconsider An Béal Bocht as a complex network of intertextual references that governs its structural and aesthetic design in a multiplicity of ways" (143-144).

${ }^{25}$ Cf. Farnon: "The 1926 saw the establishment of An Gúm, the government-sponsored publishing house .... As texts in the Irish language began to proliferate, Gaelic literature became inextricably bound to state policy. It was the government's aim to promote the Irish language, there was no room for concern for the creative writer, and any type of experimental writing was discouraged. As a result, the novels and memoirs which An Gúm published were written in impeccable Irish but were often devoid of literary merit" (89).

${ }^{26}$ As stressed by Diarmuid Ó Giolláin: "Various [Irish] writers recognized the relationship between folklore and underdevelopment and understood that to 'save' folklore was to preserve underdevelopment" (144).

${ }^{27}$ See, in particular, Briody, "Dead Clay" 60-64; and Ó Giolláin 149-153.

28 According to Diarmuid Ó Giolláin, Máirtin Ó Cadhain, as well as Patrick Kavanagh (another writer who criticized the work of folklorists), "showed the artist's disdain for the pedantry of the scholar, but also used the folk culture of his own background to enrich his writings" (153).

${ }^{29}$ See Briody, The Irish 444-472, for an overview of the main "neglects" attributable to IFC in its work of collecting.

\section{Works Cited}

Anttonen, Pertti. Tradition through Modernity. Postmodernism and the Nation-State in Folklore Scholarship. Helsinki: Finnish Literature Society, 2005.

Bauman, Richard, ed. Folklore, Cultural Performances, and Popular Entertainments. New York: Oxford University Press, 1992.

Ben Amos, Dan. "The Seven Strands of Tradition: Varieties in Its Meaning in American Folklore Studies". Journal of Folklore Research 21. 2-3 (1984): 97-131.

Bendix, Regina. In search of Authenticity: The Formation of Folklore Studies. Madison: University of Wisconsin Press, 1997.

Briody, Mícheál. The Irish Folklore Commission 1935-1970: History, Ideology, Methodology. Helsinki: Studia Fennica Folkloristica 17, 2007. ."'Dead Clay and Living Clay': Máirtin Ó Cadhain's criticisms of the work of the Irish Folklore Commission”. Approaching Religion 4. 1 (2014): 55-65.

Bronzini, Giovanni Battista. Folk-Lore e cultura tradizionale. Bari: Adriatica editrice, 1976. . Cultura popolare: dialettica e contestualità. Bari: Dedalo, 1980.

Carrassi, Vito. The Irish Fairy Tale: A Narrative Tradition from the Middle Ages to Yeats and Stephens. Roma and Lanham: John Cabot University Press-University of Delaware Press, 2012. 
Casanova, Pascale. The World Republic of Letters. Translated by M.B. DeBevoise. Cambridge (Mass.) and London: Harvard University Press, 2004.

Clissmann, Anne. Flann O'Brien. A Critical Introduction to His Writings: The Story-Teller's Book Web. Dublin and New York: Gill \& McMillan and Barnes \& Noble, 1975.

Conrad, JoAnn. "The Storied Time of Folklore". Western Folklore 73. 2/3 (2014): 323-352.

Danaher, Kevin. "Stories and Storytelling in Ireland". Folk Literature of the British Isles. K.M. Briggs, S. Ó Catháin, et alii. London and Folkestone: Scarecrow Press, 1978. 107-114.

Denvir, Gearóid. "Decolonizing the Mind: Language and Literature in Ireland". New Hibernia Review 1. 1 (1997): 44-68.

Dundes, Alan. "Nationalistic Inferiority Complexes and the Fabrication of Fakelore: A Reconsideration of Ossian, the Kinder- und Hausmärchen, the Kalevala, and Paul Bunyan". Journal of Folklore Research 22. 1 (1985): 5-18.

- ed. International Folkloristics. Classic Contributions by the Founders of Folklore. Lanham: Rowman and Littlefield Publishers, 1999.

Farnon, Jane. "Motifs of Gaelic Lore and Literature in An Béal Bocht". Conjuring Complexities. Essays on Flann O'Brien. Ed. Anne Clune and Tess Hurson. Belfast: The Queen's University of Belfast, 1997. 89-109.

Foster, John W. Fictions of the Irish Literary Revival: A Changeling Art. Syracuse: Syracuse University Press, 1987.

Honko, Lauri. Theoretical Milestones: Selected Writings of Lauri Honko. Ed. Pekka Hakamies and Anneli Honko. Helsinki: Suomalainen Tiedeakatemia, 2013.

Hopper, Keith. Flann O'Brien: A Portrait of the Artist as a Young Post-Modernist. Cork: Cork University Press, 2011.

Hovi, Tuomas. "Authenticity, Dracula Tourism and the Folklore Process". Folklore Fellows' Network 45 (2014): 4-11.

Hultin, Neil C. "Anglo-Irish Folklore from Clonmel: T.C. Croker and British Library add. 20099". Fabula 27 (1986): 288-307.

Hutchinson, John. The Dynamics of Cultural Nationalism. The Gaelic Revival and the Creation of the Irish Nation State. London: Allen \& Unwin, 1987.

Hyde, Douglas. Beside the Fire: A Collection of Irish Gaelic Folk Stories. London: D. Nutt, 1980.

. "The Necessity for De-Anglicising Ireland". The Revival of Irish Literature. Ed. Charles G. Duffy, George Sigerson and Douglas Hyde. London: T. Fisher Unwin, 1894. 117-161.

Jason, Heda. "About the 'Authentic' and the 'Spurious"'. Estudos de Literatura Oral 3 (1997): 75-79.

McKibben, Sarah. "The Poor Mouth: A Parody of (Post) Colonial Irish Manhood". Research in African Literatures 34. 4 (2003): 96-114.

McMahon Timothy G. Grand Opportunity: the Gaelic Revival and Irish Society,1893-1910. Syracuse: Syracuse University Press, 2008.

Murphy, Neil. 'Myles na gCopaleen, Flann O'Brien, and An Béal Bocht: Intertextuality and Aesthetic Play". Flann O'Brien: Contesting Legacies. Ed. Ruben Borg, Paul Fagan and Werner Huber. Cork: Cork University Press, 2014. 143-155.

na gCopaleen, Myles. An Béal Bocht. F. O’Brien. The Complete Novels. New York, London and Toronto: Everyman's Library, 2007.

Ó Catháin, Seamas. "Folklore, Preserving the People's Past". Folk Literature of the British Isles. K.M. Briggs, S. Ó Catháin, et alii. London and Folkestone: Scarecrow Press, 1978. 98-106. 
Ó Coileáin, Seán. “Oral or Literary? Some Strands of the Argument”. Studia Hibernica 17-18 (1977): 7-35.

Ó Danachair, Caoimhin [Danaher, Kevin]. "Oral Tradition and the Printed Word". Irish University Review 9. 1 (1979): 31-41.

Ó Giolláin, Diarmuid. Locating Irish Folklore: Tradition, Modernity, Identity. Cork: Cork University Press, 2000.

O'Leary, Philip. The Prose Literature of the Gaelic Revival: 1881-1921. Ideology and Innovation. University Park: The Pennsylvania State University Press, 1994.

- Gaelic Prose in the Irish Free State: 1922-1939. University Park: The Pennsylvania State University Press, 2004.

Ong, Walter J. Orality and Literacy. The Technologizing of the Word. Abingdon-New York: Routledge, 1988.

Oring, Elliott. Folk Groups and Folklore Genres: An Introduction. Logan: Utah State University Press, 1986.

Schenda, Rudolf. "Semiliterate and Semi-Oral Processes". Translated by Ruth. B. Bottigheimer. Marvels and Tales 21.1 (2007): 127-140.

Thuente, Mary H. "W.B. Yeats and Nineteenth-Century Folklore". The Journal of Irish Literature 6 (1977): 64-79.

Wäppling, Eva. Four Irish Legendary Figures in At Swim-Two-Birds: A Study of Flann O'Brien's Use of Finn, Suibhne, the Pooka and the Good Fairy. Uppsala: Uppsala Universitet, 1984.

Zimmermann, Georges D. The Irish Storyteller. Dublin: Four Courts, 2001.

Received: 10 November 2016. Revised version accepted: 5 February 2017.

Vito Carrassi holds a $\mathrm{PhD}$ in Literary Sciences (Modern Comparative Literatures) and is a member of EFACIS (European Federation of Associations and Centres of Irish Studies), SIEF (Société Internationale d'Ethnologie et Folklore) and IFOBS (International Flann O'Brien Society). He has held university courses on Folkloristics (University of Bari) and is currently a contract professor of Cultural Anthropology at the University of Basilicata. His research focuses particularly on the intersection and interference between folklore and literature, on the history and theory of folk narrative genres, on folk revival/ism and on ritual and popular traditions, topics about which he has written several essays and articles. His main work, Il fairy tale nella tradizione narrativa irlandese, has been translated and published in English as The Irish Fairy Tale: A Narrative Tradition from the Middle Ages to Yeats and Stephens (2012). He is also a translator of historical, anthropological and sociological monographs, as well as author of novels and short stories.

vito1976@interfree.it 